Journal of Cleaner Production 202 (2018) 81-87

https://doi.org/10.1016/j.jclepro.2018.07.260

\title{
Bio-lubricants production from fish oil residue by transesterification with trimethylolpropane
}

Beatriz Angulo, ${ }^{\mathrm{a}, \mathrm{b}}$ José M. Fraile, ${ }^{* a}$ Laura Gil $^{\mathrm{b}}$ and Clara I. Herrerías ${ }^{\mathrm{a}}$

a Instituto de Síntesis Química y Catálisis Homogénea (ISQCH), Facultad de Ciencias, CSIC-Universidad de Zaragoza, C/ Pedro Cerbuna 12, E-50009 Zaragoza, Spain. Email:jmfraile@unizar.es

${ }^{b}$ Solutex GC, SL,, P. I. El Zafranar, E-50550 Mallén (Zaragoza), Spain

\begin{abstract}
The fatty acid ethyl esters mixture, a fish oil residue obtained after the extraction of omega-3 polyunsaturated fatty esters, has been converted into mixtures of mono-, di-, and triesters of trimethylolpropane by transesterification at $100-140^{\circ} \mathrm{C}$ under vacuum with sodium ethoxide as catalyst. This method has shown to be more efficient than the enzymatic transesterification using commercially available lipases. The crude reaction mixture ( $84 \%$ conversion of ethyl esters), enriched in trimethylolpropane triesters $(96 \%$ selectivity) was characterized and its properties compared with those of the starting ethyl esters mixture and the trimethylolpropane esters obtained from vegetal sources.
\end{abstract}

Keywords: bio-lubricants; waste fish oil; transesterification; trimethylolpropane

\section{Abbreviations}

ASTM American Society for Testing and Materials

DE Diesters

DHA Docosahexaenoic acid

EPA Eicosapentaenoic acid

EtONa Sodium ethoxide 


$\begin{array}{ll}\text { FAs } & \text { Fatty Acids } \\ \text { FAEEs } & \text { Fatty Acid Ethyl Esters } \\ \text { FAMEs } & \text { Fatty Acid Methyl Esters } \\ \text { ISO } & \text { International Standards Organization } \\ \text { ISO-VG } & \text { International Standards Organization Viscosity Grade } \\ \text { ME } & \text { Monoesters } \\ \text { MeONa } & \text { Sodium methoxide } \\ \text { MUFAs } & \text { Monunsaturated Fatty Acids } \\ \text { NMR } & \text { Nuclear Magnetic Resonance spectroscopy } \\ \text { PUFAs } & \text { Polyunsaturated Fatty Acids } \\ \text { SFAs } & \text { Saturated Fatty Acids } \\ \text { TE } & \text { Triesters } \\ \text { TMP } & \text { Trimethylolpropane } \\ \text { UNE } & \text { Una Norma Española (A spanish regulation (or standard)) }\end{array}$

\section{Introduction}

Omega-3 fatty acids, abundant in fish oil, are engaged in various physiological actions as essential fatty acids and they play an important role in homeostatic maintenance in the body (Tokuyama and Nakamoto, 2014). Given this important role of omega-3 polyunsaturated fatty acids (PUFAs) in health (Ruxton et al., 2005), many nutrition products are enriched with omega-3 concentrates from natural sources to compensate their low consumption in the typical diets of many developed countries. In spite of the search for alternative sources of omega-3 fatty acids (Ward and Singh, 2005), fish remains as the main feedstock to produce omega-3 concentrates (Rubio-Rodríguez et al., 2010). Their manufacture implies the separation of the omega-3 PUFAs from the rest of fatty acids (FAs) present in the fish oil, which are then considered as a waste.

Fish industry uses a billion tons of fish for edible purpose, which generates a very large amount of waste. Around 5.2 million tons/year in the European Union (Lopes et al., 2015) are produced of this non-edible waste. A considerable effort is being done to produce biofuels from those fish wastes, mainly by extraction of the lipids and transformation into biodiesel (Dave et al., 2014; Yuvaraj et al., 2016). Although specific installations have been designed, and the process through chemical transesterification with basic catalysts has been optimized, there is a low interest in the manufacturing of this bioproduct when 
the fish oil waste keeps high quality, in terms of characteristics as acid value, oxidation parameters, and presence of contaminants (such as dioxins, heavy metals, polychlorobiphenyls and polyaromatic hydrocarbons). In those cases, when the value of the waste is higher, searching of new valorization alternatives would be desirable to obtain specific biobased products. This solution has been already proposed as an alternative for biodiesel manufacturers to extend the potential sales market (Kleinaté et al., 2014).

This strategy has been very recently explored from non-edible Tilapia (Oreochromis niloticus) oil obtained from viscera (Valle et al., 2018). In this case, methyl esters were epoxidized and the epoxides opened with medium size alcohols, a method also used in the valorization of other waste oils, such as cooking oil (Borugadda and Goud, 2016). Trimethylolpropane (TMP) fatty esters are considered as biolubricants (Panchal et al., 2017; Syahir et al., 2017; Zainal et al., 2018) with improved stability properties, in comparison with the analogous triglycerides (Sripada et al., 2013). TMP triesters have been prepared by esterification of TMP with free fatty acids or by transesterification of fatty acid methyl esters (FAMEs). In the first case, the esterification has been carried out using either acid catalysis (Åkerman et al., 2011 a; Kamalakar et al., 2013) or immobilized lipases (Åkerman et al., 2011b). On the other hand, transesterification has been described using either basic catalysis, usually sodium (Yunus et al., 2005) or calcium (Gryglewicz et al., 2003) methoxide, or immobilized lipases (Cavalcanti da Silva et al., 2015; Uosukainen et al., 1998). However, this strategy had not been applied to waste or fish oils.

In this paper, we compare the chemical and enzymatic methods of transesterification of TMP with methyl oleate, as a model, and the subsequent application of the best method to the fatty acid ethyl esters waste mixture from fish oil after PUFA extraction. Some of the key properties to be usable as biolubricant have been also measured.

\section{Materials and methods}

\section{Nuclear Magnetic Resonance (NMR) spectroscopy.}

Proton $\left({ }^{1} \mathrm{H}\right)$ spectra were recorded in a Bruker Avance 400 at a frequency of $400 \mathrm{MHz}$ and the chemical shifts are expressed in ppm. Deuterated chloroform $\left(\mathrm{CDCl}_{3}\right)$ was used as solvent and reference (7.26 ppm). All the reactions were monitored (conversion and selectivity) by ${ }^{1} \mathrm{H}-\mathrm{NMR}$. 


\section{Enzymatic transesterification reactions.}

A mixture of methyl oleate (2 g, $6.75 \mathrm{mmol}$ ), Novozym 435 (89 mg, 4\% w/w), TMP (232 $\mathrm{mg}, 1.73 \mathrm{mmol}$ ) and in some cases a solvent (acetone or tert-butanol, $2 \mathrm{~mL}$ ) was stirred at 150 r.p.m. and $45^{\circ} \mathrm{C}$ (unless otherwise stated in table 1) for $4-24$ h. Some of the reactions were also carried out under vacuum (1 mbar). After the corresponding reaction time, the immobilized enzyme was filtered off and washed with acetone (15 mL). Finally, the excess of alcohol and the organic solvent were eliminated under reduced pressure.

\section{Base-catalyzed transesterification reactions.}

A mixture of methyl oleate (2 g, $6.75 \mathrm{mmol})$, TMP (226.4 mg, $1.69 \mathrm{mmol})$ and EtONa $(20 \mathrm{mg}, 1 \% \mathrm{w} / \mathrm{w}, 1.47 \mathrm{mmol})$ was stirred and heated at $140^{\circ} \mathrm{C}$ under vacuum (1 mbar) for $6 \mathrm{~h}$. The reaction was quenched by adding $10 \mathrm{~mL}$ of water and then $\mathrm{HCl}(35 \% \mathrm{w} / \mathrm{w})$ until neutral $\mathrm{pH}$. The mixture was extracted with $\mathrm{CH}_{2} \mathrm{Cl}_{2}(4 \times 10 \mathrm{~mL})$. The combined organic phases were dried with anhydrous $\mathrm{MgSO}_{4}$ and filtered, and the solvent was evaporated under reduced pressure.

Optimized method to obtain triesters from the fish oil fatty esters mixture: $8.9 \mathrm{~g}$ of ethyl esters mixture (around $30 \mathrm{mmol}), 1.00 \mathrm{~g}$ of TMP (7.15 mmol) and $89 \mathrm{mg}$ of EtONa (1.46 mmol) were heated at $100^{\circ} \mathrm{C}$ under vacuum $(1 \mathrm{mbar})$ for $3 \mathrm{~h}$. The treatment was carried out in the same way as described above with $15 \mathrm{~mL}$ of water and $4 \times 15 \mathrm{~mL} \mathrm{CH}_{2} \mathrm{Cl}_{2}$ extractions.

Characterization of the properties of the TMP fatty esters.

The density at $20^{\circ} \mathrm{C}$ was determined according to the UNE 84156:2000 method. The kinematic viscosities were determined at $40^{\circ} \mathrm{C}$ and $100^{\circ} \mathrm{C}$ based on the ASTM D445 method. The viscosity index was calculated from kinematic viscosities according to ASTM D-2270-10 method. The pour point was determined according to ASTM D595014. The flash point was determined according to ASTM D92-16b.

\section{Results and discussion}

\section{Determination of the results by NMR}

Although the results can be determined by gas chromatography, as reported in the literature (Yunus et al., 2005; Sripada et al., 2013), it requires an additional 
functionalization (silanization) step, and the identification and integration of all the peaks of the real sample, which is a complex mixture of fatty esters (see below). Thus, we envisaged the use of ${ }^{1} \mathrm{H}-\mathrm{NMR}$, a method that has shown its usefulness in the analysis of vegetable oils (Popescu et al., 2015). The key point was to distinguish the protons of TMP after one, two or three esterifications, which would allow directly quantifying the molar ratio of mono- (ME), di- (DE) and triesters (TE) of TMP. The identification of the signals was carried out using reaction mixtures with different conversions and ratios of products, as can be seen in Figure 1. The $\mathrm{CH}_{2} \mathrm{OH}$ groups shift from 3.73 ppm in TMP (6H) to 3.58$3.51 \mathrm{ppm}$ in ME (two doublets corresponding to diastereotopic protons, $4 \mathrm{H}$ ) and to 3.39 ppm in DE (2H). The esterified groups ( $\left.\mathrm{CH}_{2} \mathrm{OOC}-\right)$ appear at higher chemical shifts, 4.17 ppm in ME (2H), $4.01 \mathrm{ppm}$ in DE $(4 \mathrm{H})$ and $4.00 \mathrm{ppm}$ in TE $(6 \mathrm{H})$. These two signals are slightly overlapped, but they can be easily deconvoluted. All those ester signals are different from those of the starting fatty esters, $4.10 \mathrm{ppm}(\mathrm{q}, 2 \mathrm{H})$ of ethyl esters and 3.66 ppm $(\mathrm{s}, 3 \mathrm{H})$ of methyl ester (not shown in Figure 1). The $-\mathrm{CH}_{2}-\mathrm{COO}$ signal at 2.37-2.25 ppm was used as reference $(2 \mathrm{H})$ to calculate the conversion and to check the absence of a significant amount of hydrolysis to fatty acids.

\section{Enzymatic transesterification of methyl oleate with TMP}

Novozym 435 (Candida antarctica) lipase was chosen as a typical successful enzymatic catalyst for transesterification reactions (Linko et al., 1998; Åkerman et al., 2011b; Gryglewicz et al., 2013; Cavalcanti da Silva et al., 2015). In a first set of experiments, the reaction was carried out with the stoichiometric amount of reagents or a slight excess of methyl oleate (oleate/TMP molar ratio $=3.0-3.9)$ under atmospheric pressure, with $4 \%$ $\mathrm{w} / \mathrm{w}$ of enzyme and $15 \% \mathrm{w} / \mathrm{w}$ of water. Moderate conversion of methyl oleate was obtained (24-49\%), even after $24 \mathrm{~h}$, but only hydrolysis to oleic acid was observed. Only in the case of carrying out the reaction under vacuum ( 1 mbar), to shift the equilibrium by the elimination of methanol from the reaction medium, a low conversion to TMP esters $(16 \%)$ was obtained. Thus, the rest of experiments were carried out in the absence of water, either with a solvent to assist the contact of the enzyme with the reagents or in the absence of solvent. Some reactions were carried out under vacuum. The reaction conditions and the results are collected in Table 1.

At atmospheric pressure (entry 1), the conversion is very low, 10\% to TMP esters and 7\% to oleic acid (hydrolysis). One possible explanation is the poor contact between the hydrophilic environment of the enzyme and the hydrophobic reagents. Acetone was used 
in an attempt to improve the contact, but no significant improvements were obtained (entries 2 and 3). The application of dynamic vacuum does not improve either the results, unless the temperature is raised to $100^{\circ} \mathrm{C}$, although the result is highly dependent on the amount of enzyme. The best result (47\% conversion, with only $14 \%$ of hydrolysis, entry 6) was obtained with only $40 \mathrm{mg}$ of enzyme, at $100^{\circ} \mathrm{C}$ and $1 \mathrm{mbar}$, leading to a mixture of TMP diester (DE) and triester (TE) in 82/18 ratio. The use of acetone as a co-solvent at lower temperature $\left(60^{\circ} \mathrm{C}\right)$ reduces the hydrolysis to only $7 \%$, together with a change in selectivity, as a mixture of $\mathrm{ME}$ and $\mathrm{DE}(55 / 44)$ is obtained (entry 8$)$. The dynamic vacuum eliminates in fact the acetone from the reaction mixture, and then a reaction was carried out under atmospheric pressure for $24 \mathrm{~h}$, to ensure the mixing of enzyme and reagents, and then $12 \mathrm{~h}$ under vacuum (entry 9), with a oleate/TMP molar ratio of 1 , to favor the formation of ME. However, this strategy led to lower oleate conversion. The best result was obtained at atmospheric pressure, by using acetone for $6 \mathrm{~h}$, and then evaporation of the solvent before continuing the reaction for an additional $18 \mathrm{~h}$ period (entry 10). In this way, in spite of the larger amount of enzyme, the conversion was only slightly better, but the hydrolysis was nearly suppressed.

\section{Base-catalyzed transesterification of methyl oleate with TMP}

Given the disappointing results obtained with Novozym 435, the base catalyzed transesterification was tried, using sodium alkoxides (Table 2). The reactions were carried out without solvent at $140^{\circ} \mathrm{C}$ under vacuum, given that the conversion at atmospheric pressure was very low (entry 1). The first advantage of the base catalyzed transesterification is the lack of hydrolysis, as oleic acid was not detected in any of the reactions. With only $1 \%$ sodium ethoxide $(\mathrm{EtONa})$, it is possible to get a nearly complete conversion of methyl oleate by using an excess of TMP (entries 2 and 3), leading to a mixture of ME (as the main component) and DE. The TE can be obtained under similar conditions, by only changing the oleate/TMP ratio to a slight excess of oleate, with also nearly total conversion (entries 4 and 5), given that the theoretical maximum is $75 \%$.

The use of EtONa leads also to a small amount of ethyl oleate, and hence sodium methoxide $(\mathrm{MeONa})$ was also tested to prevent this effect. The results were not so favorable, with lower conversion under the same conditions (entry 7 vs entry 4). The equimolecular mixture of oleate and TMP gives a nearly statistical distribution of ME, DE and TE (entry 6). 
Table 1. Results of the transesterification of methyl oleate with TMP using Novozym 435 lipase. ${ }^{\text {a }}$

\begin{tabular}{|c|c|c|c|c|c|c|c|c|c|c|c|}
\hline \multirow[t]{2}{*}{ Entry } & \multirow{2}{*}{$\begin{array}{l}\text { Oleate/TMP } \\
\text { molar ratio }\end{array}$} & \multirow{2}{*}{$\begin{array}{l}\text { Novozym } \\
\text { mass (mg) }\end{array}$} & \multirow[t]{2}{*}{ Solvent } & \multirow[t]{2}{*}{$\mathrm{P}$} & \multirow{2}{*}{$\begin{array}{l}\mathrm{T} \\
\left({ }^{\circ} \mathrm{C}\right)\end{array}$} & \multirow{2}{*}{$\begin{array}{l}\text { time } \\
\text { (h) }\end{array}$} & \multirow{2}{*}{$\begin{array}{l}\text { Conv. } \\
(\%)^{b}\end{array}$} & \multirow{2}{*}{$\begin{array}{l}\text { Hydrol. } \\
(\%)^{b}\end{array}$} & \multicolumn{3}{|c|}{ Selectivity (\%) } \\
\hline & & & & & & & & & $\mathrm{ME}$ & $\mathrm{DE}$ & TE \\
\hline 1 & $3.9: 1$ & 89 & - & atm & 45 & 24 & 17 & 7 & 58 & 42 & 0 \\
\hline 2 & $3.9: 1$ & 40 & Acetone $^{\mathrm{c}}$ & atm & 45 & 24 & 10 & 6 & 77 & 23 & 0 \\
\hline 3 & $3: 1$ & 40 & Acetone & atm & 60 & 48 & 12 & 8 & 100 & 0 & 0 \\
\hline 4 & $3.9: 1$ & 89 & - & $1 \mathrm{mbar}$ & 45 & 6 & 13 & 9 & 63 & 32 & 5 \\
\hline 5 & $3.9: 1$ & 89 & $\mathrm{t}-\mathrm{BuOH}$ & $1 \mathrm{mbar}$ & 45 & 6 & 8 & 3 & 86 & 11 & 3 \\
\hline 6 & $3: 1$ & 40 & - & $1 \mathrm{mbar}$ & 100 & 6 & 47 & 14 & 0 & 82 & 18 \\
\hline 7 & $3: 1$ & 150 & - & 1 mbar & 100 & 6 & 16 & 10 & 67 & 33 & 0 \\
\hline 8 & $3: 1$ & 40 & Acetone & $1 \mathrm{mbar}$ & 60 & 36 & 47 & 7 & 55 & 44 & 1 \\
\hline 9 & $1: 1$ & 40 & Acetone & atm-1 mbar & 60 & $36^{\mathrm{d}}$ & 27 & 8 & 66 & 34 & 0 \\
\hline 10 & $1: 1$ & 100 & Acetone $^{\mathrm{e}}$ & atm & 60 & $24^{\mathrm{e}}$ & 53 & 1 & 61 & 39 & 0 \\
\hline
\end{tabular}

$\overline{{ }^{a}}$ Reaction conditions: methyl oleate $(2 \mathrm{~g}, 6.75 \mathrm{mmol})$, Novozym 435 (mass indicated in table), TMP (molar ratio indicated in table), solvent $(2 \mathrm{~mL}) .{ }^{\mathrm{b}}$ Total conversion of methyl oleate and conversion to oleic acid (hydrolysis). ${ }^{\mathrm{c}}$ Only $0.43 \mathrm{~mL}$ of acetone. ${ }^{\mathrm{d}}$ Reaction carried out for $24 \mathrm{~h}$ at atmospheric pressure and 12 $\mathrm{h}$ under vacuum. ${ }^{\mathrm{e}}$ Acetone was evaporated after $6 \mathrm{~h}$ and the reaction was continued without solvent. 
Table 2. Results of the transesterification of methyl oleate with TMP using basic catalysts. ${ }^{\text {a }}$

\begin{tabular}{|c|c|c|c|c|c|c|c|c|c|}
\hline \multirow[t]{2}{*}{ Entry } & \multirow{2}{*}{$\begin{array}{l}\text { Oleate/TMP } \\
\text { molar ratio }\end{array}$} & \multirow[t]{2}{*}{ Catalyst $(\%)^{b}$} & \multirow[t]{2}{*}{$\mathrm{P}$} & \multirow{2}{*}{$\begin{array}{l}\mathrm{T} \\
\left({ }^{\circ} \mathrm{C}\right)\end{array}$} & \multirow{2}{*}{$\begin{array}{l}\text { time } \\
\text { (h) }\end{array}$} & \multirow{2}{*}{$\begin{array}{l}\text { Conv. } \\
(\%)\end{array}$} & \multicolumn{3}{|c|}{ Selectivity (\%) } \\
\hline & & & & & & & $\mathrm{ME}$ & $\mathrm{DE}$ & $\mathrm{TE}$ \\
\hline 1 & $1: 4$ & EtONa $(1 \%)$ & atm & 140 & 24 & 22 & 90 & 10 & 0 \\
\hline 2 & $1: 4$ & EtONa $(1 \%)$ & 1 mbar & 140 & 6 & 94 & 61 & 37 & 2 \\
\hline 3 & $1: 3$ & EtONa $(1 \%)$ & 1 mbar & 140 & 6 & 95 & 67 & 31 & 2 \\
\hline 4 & $4: 1$ & EtONa $(1 \%)$ & 1 mbar & 140 & 6 & 71 & 0 & 12 & 88 \\
\hline 5 & $4: 1$ & EtONa $(5 \%)$ & 1 mbar & 140 & 6 & 78 & 0 & 6 & 94 \\
\hline 6 & $1: 1$ & $\mathrm{MeONa}(1 \%)$ & 1 mbar & 140 & 6 & 64 & 16 & 49 & 35 \\
\hline 7 & $4: 1$ & $\mathrm{MeONa}(1 \%)$ & 1 mbar & 140 & 6 & 60 & 5 & 7 & 88 \\
\hline 8 & $3.2: 1$ & $\mathrm{MeONa}(1 \%)$ & 1 mbar & 120 & 6 & 30 & 41 & 38 & 21 \\
\hline 9 & $3.2: 1$ & $\mathrm{MeONa}(1 \%)$ & 50 mbar & 120 & 6 & 15 & 100 & 0 & 0 \\
\hline 10 & $3.9: 1$ & $\mathrm{MeONa}(0.7 \%)$ & $60 \mathrm{mbar}$ & 130 & 6 & 7 & 87 & 13 & 0 \\
\hline
\end{tabular}

${ }^{\mathrm{a}}$ Scale: $2 \mathrm{~g}$ of methyl oleate $(6.75 \mathrm{mmol}) .{ }^{\mathrm{b}} \% \mathrm{w} / \mathrm{w}$ with respect to methyl oleate. 
Lowering the reaction temperature (entry 8) and increasing the pressure (entries 9 and 10) produce a significant drop in activity, as demonstrated by the lower conversions, with an improved selectivity to ME. Thus, the use of EtONa was chosen as the best transesterification method to perform the reaction from the fish oil fatty ethyl esters mixture.

\section{Composition of the fatty esters mixture from fish oil}

The starting material for Solutex is the fish oil, in the form of ethyl esters (FAEEs), and the PUFAs are extracted and concentrated following sustainable methodologies. After this process, Solutex generates 500-600 ton/year of a waste mixture of FAEEs that is currently valorized as biodiesel. The composition of this waste mixture is determined by gas chromatography (Table 3, Figure S1). As can be seen, it contains around $50 \mathrm{wt} \%$ of saturated FAs (SFAs), mainly palmitic acid but also myristic and stearic ones. Monounsaturated FAs (MUFAs), mainly palmitoleic and oleic, account for $25 \mathrm{wt} \%$, whereas the content of polyunsaturated acids is also around $25 \mathrm{wt} \%$, with eicosapentaenoic acid (EPA) as the most abundant one. In the ${ }^{1} \mathrm{H}-\mathrm{NMR}$ spectrum (Figure S2), the total count of protons is around 34-36, with an average of 1-1.5 insaturations per fatty acid chain. Thus, the averaged molecular weight of the sample, used for calculation of molar ratios, was taken as that of methyl oleate $\left(\mathrm{C}_{19} \mathrm{H}_{36} \mathrm{O}_{2}\right)$.

Table 3. Fatty acid ethyl esters composition of fish oil waste.

\begin{tabular}{lll}
\hline Type & Fatty acid & $\% \mathrm{w} / \mathrm{w}$ \\
\hline SFAs & Myristic (C14:0) & 13.5 \\
& Palmitic (C16:0) & 29.6 \\
& Stearic (C18:0) & 3.8 \\
\hline MUFAs & Palmitoleic (C16:1 n-7) & 13.7 \\
& Oleic (C18:1 n-9) & 9.1 \\
& C18:1 n-7 & 3.6 \\
\hline PUFAs & C16:4 n-1 & 4.1 \\
& Linoleic (C18:2 n-6) & 1.4 \\
& Stearidonic (C18:4 n-3) & 3.6 \\
& EPA (C20:5 n-3) & 11.0 \\
& DHA (C22:6 n-3) & 1.8 \\
\hline
\end{tabular}




\begin{tabular}{ll}
\hline Others & 4.8 \\
\hline
\end{tabular}

Transesterification of the fatty esters mixture from fish oil

The results were determined by ${ }^{1} \mathrm{H}$ NMR as explained above. One full spectrum is shown in Figure S3.

In a first set of experiments, the reactions were carried out with $5 \mathrm{~g}$ of the mixture of fatty ethyl esters at $140^{\circ} \mathrm{C}$ under vacuum ( $\left.1 \mathrm{mbar}\right)$ for $6 \mathrm{~h}$. The effect of the fatty esters/TMP molar ratio was studied at a fixed amount of EtONa as catalysts, $1 \% \mathrm{w} / \mathrm{w}$ with respect to the mass of esters. The results are summarized in Figure 2. As can be seen, the conversion of FAEEs is nearly quantitative (>95\%) up to a FAEEs/TMP molar ratio of 2.7:1, slightly lower than the stoichiometric amount. As expected, the major products at low ratio are ME (66\% selectivity), whereas the amount of DE and TE increases at higher ratios. The use of the stoichiometric amount (3:1) leads to a slight decrease in the conversion, only $86 \%$ that can reach $93 \%$ at longer reaction time $(8 \mathrm{~h})$, with the highest selectivity to TE (79\%).

Those optimal conditions of time and molar ratio were used to check the effect of the amount of catalyst (Figure 3). As expected, a lower amount $(0.7 \% \mathrm{w} / \mathrm{w})$ leads to a slower reaction, with both lower conversion and lower selectivity to TE. However, rather unexpectedly, the use of a higher amount of sodium ethoxide is also detrimental for the final result. This effect had been already observed in other transesterification reactions and it was attributed to the presence of free fatty acids traces (Anastopoulos et al., 2009). Some of those reactions were scaled up (Table 4). In a first step, they were conducted at $50 \mathrm{~g}$ scale with different FAEEs/TMP molar ratios, trying to obtain mixtures enriched in $\mathrm{ME}, \mathrm{ME}+\mathrm{DE}$ and TE. Although TE has commonly been the target molecule to be used as lubricant, the presence of partially esterified molecules ME and DE has been described as positive for the lubrication properties (Abu Bakar et al., 2007), and hence the optimization of their synthesis would also be of interest. The conversions were quantitative or almost quantitative, slightly better than those obtained at lower scale. The selectivities were very similar, leading to a mixture highly enriched in TE ( $82 \%$, entry 1$)$, in $\mathrm{ME}(83 \%$, entry 3$)$, or in $\mathrm{ME}+\mathrm{DE}(43 \%+41 \%$, entry 2$)$. The results were nearly identical in a further step in $100 \mathrm{~g}$ scale (entries 4 and 5). However, in $500 \mathrm{~g}$ scale the results were slightly worse, with only $90 \%$ conversion and $60 \%$ TE selectivity after $12 \mathrm{~h}$. The increase in viscosity of the reaction mixture and the problems in mixing with a 
magnetic stirrer may account for this behavior, indicating that a different type of reactor would be necessary for such scale.

Finally, the objective was to obtain a mixture with a selectivity to TE higher than $90 \%$ in order to check its suitability as lubricant. The use of a higher excess of fatty esters (molar ratio $4: 1)$ under the same conditions $\left(140^{\circ} \mathrm{C}, 1 \mathrm{mbar}, 1 \% \mathrm{w} / \mathrm{w} \mathrm{EtONa}\right)$ did not improve the selectivity to TE. However, when the reaction was carried out at $100^{\circ} \mathrm{C}, 96 \% \mathrm{TE}$ selectivity was obtained with $84 \%$ conversion after only $3 \mathrm{~h}$. A possible explanation for this result might be the partial elimination of some of the reagents (mainly ethyl myristate) under vacuum at higher temperature, which also would explain the conversion higher than the theoretical maximum (75\%), although this might also be due to an incorrect estimation of the averaged molecular weight of the fatty esters mixture.

Table 4. Scaling up results of the transesterification of the mixture of FAEEs with TMP. ${ }^{\text {a }}$

\begin{tabular}{|c|c|c|c|c|c|c|c|}
\hline \multirow[t]{2}{*}{ Entry } & \multirow[t]{2}{*}{ Scale } & \multirow{2}{*}{$\begin{array}{l}\text { FAEEs/TMP } \\
\text { molar ratio }\end{array}$} & \multirow{2}{*}{$\begin{array}{l}\text { time } \\
\text { (h) }\end{array}$} & \multirow{2}{*}{$\begin{array}{l}\text { Conv. } \\
(\%)\end{array}$} & \multicolumn{3}{|c|}{ Selectivity (\%) } \\
\hline & & & & & $\mathrm{ME}$ & $\mathrm{DE}$ & TE \\
\hline 1 & $50 \mathrm{~g}$ & $3: 1$ & 8 & 96 & 1 & 17 & 82 \\
\hline 2 & $50 \mathrm{~g}$ & $1.5: 1$ & 6 & 100 & 43 & 41 & 16 \\
\hline 3 & $50 \mathrm{~g}$ & $0.5: 1$ & 1 & 100 & 83 & 16 & 1 \\
\hline 4 & $100 \mathrm{~g}$ & $3: 1$ & 8 & 98 & 2 & 19 & 79 \\
\hline 5 & $100 \mathrm{~g}$ & $1.5: 1$ & 6 & 100 & 46 & 41 & 13 \\
\hline 6 & $500 \mathrm{~g}$ & $3: 1$ & 12 & 90 & 8 & 32 & 60 \\
\hline
\end{tabular}

${ }^{\mathrm{a}}$ With $1 \% \mathrm{w} / \mathrm{w}$ EtONa, at $140^{\circ} \mathrm{C}$ and 1 mbar.

Properties of the TMP fatty esters from fish oil

The possible use as lubricant is determined by the physical properties of the mixtures. Among them, viscosity and its change with temperature (viscosity index) are considered the most important ones for lubrication behavior, together with others, such as pour point and flash point, that mainly control the temperature limits of usage of the biolubricants (Mobarak et al., 2014; Zainal et al., 2018). In fact, the lubricants are classified according to their kinematic viscosities at $40^{\circ} \mathrm{C}$ in the range of $2-3200 \mathrm{cSt}$, that covers all the possible applications. All of these properties of the TMP esters were measured, as well as those of the starting mixture of ethyl esters for the sake of comparison. The results are collected in Table 5. 
Table 5. Properties of the starting ethyl esters mixture and the TMP esters.

\begin{tabular}{lll}
\hline \multirow{2}{*}{ Property } & \multicolumn{2}{l}{ Mixture of esters } \\
\cline { 2 - 3 } & Ethyl & TMP \\
\hline Density at $20^{\circ} \mathrm{C}\left(\mathrm{g} / \mathrm{cm}^{3}\right)$ & 0.862 & 0.919 \\
Kinematic viscosity at $40^{\circ} \mathrm{C}(\mathrm{cSt})$ & 3.75 & 23.16 \\
Viscosity ISO-VG & 3 & 22 \\
Kinematic viscosity at $100^{\circ} \mathrm{C}(\mathrm{cSt})$ & 1.60 & 5.81 \\
Viscosity index & - & 211 \\
Flash point $\left({ }^{\circ} \mathrm{C}\right)$ & 176 & 204 \\
Pour point $\left({ }^{\circ} \mathrm{C}\right)$ & -11 & -6 \\
\hline
\end{tabular}

Kinematic viscosity was determined at $40^{\circ} \mathrm{C}$ and $100^{\circ} \mathrm{C}$. Values were significantly higher in the case of TMP esters, compared with those of the ethyl esters mixture, from 3.75 to $23.16 \mathrm{cSt}$ at $40^{\circ} \mathrm{C}$ and from 1.6 to $5.8 \mathrm{cSt}$ at $100^{\circ} \mathrm{C}$. The ISO 3448 viscosity classification for industrial oils is based on the kinematic viscosity at $40^{\circ} \mathrm{C}$. The starting mixture of fatty ethyl esters shows an ISO VG 3, whereas TMP esters have an ISO VG 22.

These values are compared with those reported in the literature for mixtures of TMP esters from vegetal oils (Table 6). All the kinematic viscosity values are higher than the result obtained with waste fish oil. The range of kinematic viscosities at $40^{\circ} \mathrm{C}$ lays from 30 to 50 , depending on the starting material. Most of them are between 30 and $40 \mathrm{cSt}$, Jatropha oil (Nurdin et al., 2015), rapeseed oil (Uosukainen et al., 1998; Gryglewicz et al., 2003; Gryglewicz et al., 2013), olive oil (Gryglewicz et al., 2003), for rubber seed oil (Kamalakar et al., 2013), and even lard (Gryglewicz et al., 2003). Only canola biodiesel leads to a mixture of TMP esters with $40.5 \mathrm{cSt}$ (Sripada et al., 2013) and the maximum value $(50.6 \mathrm{cSt})$ is obtained with an oleic enriched fraction of sal fat oil (Kamalakar et al., 2015). Those values correspond to ISO VG 32 up to ISO VG 46. Something similar happens with kinematic viscosities at $100^{\circ} \mathrm{C}$, showing values between 7.8 and 10 , with the only exception of Jatropha, whose kinematic viscosity is lower than that of waste fish oil. One possible reason for this behavior is the larger fraction of light fatty acids $(60 \%$ with $\leq 16 \mathrm{C}$ ) in the fish oil mixture, in comparison with only $5-18 \%$ of $\mathrm{C} 16$ fatty acids in vegetal oils.

\section{Conclusions}


Fatty acid ethyl esters (FAEEs) obtained from fish oil after PUFAs extraction can be efficiently transformed in TMP esters by transesterification, using sodium ethoxide (EtONa) as catalyst. The selectivity to $\mathrm{ME}, \mathrm{DE}$ and TE can be modulated by changing the transesterification conditions. The physical properties of a high TE sample, with kinematic viscosity in the ISO VG 22 range, indicate that this waste mixture might be useful in the preparation of bio-lubricants, with properties complementary to those of the TMP esters obtained from vegetal oils, in the ISO VG 32 up to ISO VG 46 range, that may open the way to its use as hydraulic oil.

\section{Acknowledgements}

This work was financed by the Spanish Ministerio de Economía, Industria y Competitividad (project number CTQ-2014-52367-R) and the Gobierno de Aragón (E37_17R group). B.A. thanks Solutex S.L. together with the University of Zaragoza (project OTRI 2015/0231, program of industrial doctorates) for the financial support of her PhD. 
Table 6. Comparison of the properties of different mixtures of TMP esters

\begin{tabular}{|c|c|c|c|c|c|c|}
\hline \multirow[t]{2}{*}{ Starting material } & \multicolumn{2}{|c|}{ Kinematic viscosity (cSt) } & \multirow{2}{*}{$\begin{array}{l}\text { Viscosity } \\
\text { index }\end{array}$} & \multirow{2}{*}{$\begin{array}{ll}\text { Pour point } \\
\left({ }^{\circ} \mathrm{C}\right)\end{array}$} & \multirow{2}{*}{$\begin{array}{l}\text { Flash point } \\
\left({ }^{\circ} \mathrm{C}\right)\end{array}$} & \multirow[t]{2}{*}{ Reference } \\
\hline & $40^{\circ} \mathrm{C}$ & $100^{\circ} \mathrm{C}$ & & & & \\
\hline Waste fish oil & 23.16 & 5.81 & 211 & -6 & 204 & This work \\
\hline Jatropha biodiesel & 32.29 & 5.14 & 81 & -5 & n.r. ${ }^{\mathrm{a}}$ & Nurdin et al., 2015 \\
\hline Rapeseed oil & 32.9 & n.r. ${ }^{a}$ & 220 & -41 & n.r. ${ }^{a}$ & Uosukainen et al., 1998 \\
\hline Rapeseed oil & 35.34 & 7.99 & 209.2 & -15.5 & n.r. ${ }^{a}$ & Gryglewicz et al., 2003 \\
\hline Olive oil & 36.00 & 8.32 & 218.3 & -13 & n.r. ${ }^{a}$ & Gryglewicz et al., 2003 \\
\hline Lard & 37.65 & 9.06 & 234.7 & -10.5 & n.r. ${ }^{a}$ & Gryglewicz et al., 2003 \\
\hline Rapeseed oil & 38.2 & 8.4 & 205 & -18 & n.r. ${ }^{a}$ & Gryglewicz et al., 2013 \\
\hline Rubber seed oil & 38.4 & 8.6 & 212 & -6 & 299 & Kamalakar et al., 2013 \\
\hline Canola biodiesel & 40.5 & 7.8 & 204 & -66 & n.r. ${ }^{a}$ & Sripada et al., 2013 \\
\hline Oleic rich sal fat & 50.6 & 9.98 & 190 & -3 & 258 & Kamalakar et al., 2015 \\
\hline
\end{tabular}

${ }^{\mathrm{a}}$ n.r. $=$ not reported. 


\section{References}

Abu Bakar, A., Yunus, R., Luqman Chuah, A., Fakhru'l-Razi, A., 2007. Study on effect of hydroxyl group on lubrication properties of palm based trimethylolpropane esters: development of synthesis method. J. Appl. Sci. 7, 2011-2014.

Åkerman, C.O., Gabera, Y., Abd Ghanid, N., Lämsä, M., Hatti-Kaul, R. 2011a. Clean synthesis of biolubricants for low temperature applications using heterogeneous catalysts. J. Mol. Catal. B 72, 263-269.

Åkerman, C.O., Hagström, A.E.V., Mollaahmad, M.A., Karlsson, S., Hatti-Kaul, R., 2011b. Biolubricant synthesis using immobilised lipase: process optimization of trimethylolpropane oleate production. Proc. Biochem. 46, 2225-2231.

Anastopoulos, G., Zannikou, Y., Stournas, S., Kalligeros, S., 2009. Transesterification of vegetable oils with ethanol and characterization of the key fuel properties of ethyl esters. Energies 2, 362-376.

Borugadda, V.B., Goud, V.V., 2016. Improved thermo-oxidative stability of structurally modified waste cooking oil methyl esters for bio-lubricant application. J. Clean. Prod. $112,4515-4524$.

Cavalcanti da Silva, J.A., Ferreira Soares, V., Fernandez-Lafuente, R., Habert, A.C., Freire, D.M.G., 2015. Enzymatic production and characterization of potential biolubricants from castor bean biodiesel. J. Mol. Catal. B 122, 323-329.

Dave, D., Ramakrishnan, V.V., Trenholm, S., Manuel, H.; Pohling, J., Murphy, W., 2014. Marine oils as potential feedstock for biodiesel production: physicochemical characterization. J. Bioprocess. Biotech. 4, 168.

Gryglewicz, S., Piechocki, W., Gryglewicz, G., 2003. Preparation of polyol esters based on vegetable and animal fats. Biores. Technol. 87, 35-39.

Gryglewicz, S., Muszyński, M., Nowicki, J., 2013. Enzymatic synthesis of rapeseed oilbased lubricants. Ind. Crops Prod. 45, 25-29.

Kamalakar, K., Rajak, A.K., Prasad, R.B.N., Karuna, M.S.L., 2013. Rubber seed oilbased biolubricant base stocks: a potential source for hydraulic oils. Ind. Crops Prod. $51,249-257$.

Kamalakar, K., Sai Manoj, G.N.V.T., Prasad, R.B.N., Karuna, M.S.L., 2015. Influence of structural modification on lubricant properties of sal fat-based lubricant base stocks. Ind. Crops Prod. 76, 456-466. 
Kleinaité, E., Jaška, V., Tvaska, B., Matijošyté, I., 2014. A cleaner approach for biolubricant production using biodiesel as a starting material. J. Clean. Prod. 75, 4044.

Linko, Y.-Y., Lämsä, M., Wu, X., Uosukainen, E., Seppälä, J., Linko, P., 1998. Biodegradable products by lipase biocatalysis. J. Biotechnol. 66, 41-50.

Lopes, C., Anterlo, L.T., Franco-Uría, A., Alonso, A.A., Pérez-Martín, R., 2015. Valorisation of fish by-products against waste management treatments - Comparison of environmental impacts. Waste Manag. 46, 103-112.

Mobarak, H.M., Mohamad, E.N., Masjuki, H.H., Kalam, M.A., Al Mahmud, K.A.H., Habibullah, M., Ashraful, A.M., 2014. The prospects of biolubricants as alternatives in automotive application. Renew. Sustain. Energy Rev. 33, 34-43.

Nurdin, S., Misebah, F.A., Haron S.F., Yunus, R.M., 2015. Transesterification kinetics of Jatropha methyl ester and trimethylolpropane for biolubricant synthesis using Paphiaundulata shell waste. Adv. Environm. Biol. 9, 35-43.

Panchal, T.M., Patel, A., Chauhan, D.D., Thomas, M., Patel, J.V., 2017. A methodological review on bio-lubricants from vegetable oil based resources. Renew. Sustain. Energy Rev. 70, 65-70.

Popescu, R., Costinel, D., Dinca, O.R., Marinescu, A., Stefanescu, I., Ionete, R.E., 2015. Discrimination of vegetable oils using NMR spectroscopy and chemometrics. Food Control 48, 84-90.

Rubio-Rodríguez, N., Beltrán, S., Jaime, I., de Diego, S.M., Sanz, M.T., Rovira Carballido, J., 2010. Production of omega-3 polyunsaturated fatty acid concentrates: a review. Innov. Food Sci. Emerg. Technol. 11, 1-12.

Ruxton, C.H.S., Calder, P.C., Reed, S.C., Simpson, M.J.A., 2005. The impact of longchain $n-3$ polyunsaturated fatty acids on human health. Nutr. Res. Rev. 18, 113-129.

Sripada, P.K., Sharma, R.V., Dalai, A.K., 2013. Comparative study of tribological properties of trimethylolpropane-based biolubricants derived from methyl oleate and canola biodiesel. Ind. Crops Prod. 50, 95-103.

Syahir, A.Z., Zulkifli, N.W.M., Masjuki, H.H., Kalam, M.A., Alabdulkarem, A., Gulzar, M., Khuong, L.S., Harith, M.H., 2017. A review on bio-based lubricants and their applications. J. Clean. Prod. 168, 997-1016.

Tokuyama, S., Nakamoto, K., 2014. Pain as modified by polyunsaturated fatty acids, in: Watson, R.R., De Meester, F. (Eds.), Omega-3 fatty acids in brain and neurological health. Academic Press, London, pp. 131-146. 
Uosukainen, E., Linko, Y.-Y., Lämsä, M., Tervakangas, T., Linko, P., 1998. Transesterification of trimethylolpropane and rapeseed oil methyl ester to environmentally acceptable lubricants. J. Am. Oil Chem. Soc. 75, 1557-1562.

Valle, C.P.d., Rodrigues, J.S., Fechine, L.M.U.D., Cunha, A.P., Malveira, J.Q., Luna, F.M.T., Ricardo, N.M.P.S., 2018. Chemical modification of Tilapia oil for biolubricant applications. J. Clean. Prod. 191, 158-166.

Ward, O.P., Singh, A., 2005. Omega-3/6 fatty acids: alternative sources. Proc. Biochem. 40, 3627-3652.

Yunus, R., Fakhru'l-Razi, A., Ooi, T.L., Omar, R., Idris, A., 2005. Synthesis of palm oil based trimethylolpropane esters with improved pour points. Ind. Eng. Chem. Res. 44, 8178-8183.

Yuvaraj, D., Bharathiraja, B., Rithika, J., Dhanasree, S., Ezhilarasi, V., Lavanya, A., Praveenkumar, R., 2016. Production of biofuels from fish wastes: an overview. Biofuels, DOI: 10.1080/17597269.2016.1231951

Zainal, N.A., Zulkifli, N.W.M., Gulzar, M., Masjuki, H.H., 2018. A review on the chemistry, production, and technological potential of biobased lubricants. Renew. Sustain. Energy Rev. 82, 80-102. 


\section{Figure captions}

Figure 1. ${ }^{1} \mathrm{H}-\mathrm{NMR}$ spectra of different reaction mixtures of waste fish oil FAEEs with TMP. Top: incomplete conversion of ethyl esters and nearly only TE formed. Medium: mixture of ME and DE (with a small amount of TE). Bottom: mainly ME (with a small amount of DE).

Figure 2. Effect of FE/TMP molar ratio. Scale: $5 \mathrm{~g}$ of FAEEs. Conditions: 1\% EtONa (w/w FAEEs), $140^{\circ} \mathrm{C}, 6 \mathrm{~h}, 1$ mbar.

Figure 3. Effect of the amount of EtONa (w/w FAEEs). Scale: $5 \mathrm{~g}$ of FAEEs. Conditions: FAEEs/TMP molar ratio $3: 1,140^{\circ} \mathrm{C}, 8 \mathrm{~h}, 1$ mbar. 